\title{
Phytochemical Investigation and Antimicrobial Activities of Leaf Extract of Muntingia calabura Linn
}

\author{
Dr.S.Vadivelan ${ }^{1}$, Jebaseelan ${ }^{2}$, B. Edwin Jose ${ }^{3}$, Dr.R.Meera ${ }^{4}$, S.Manikandan ${ }^{5}$, Dr.R.Kalirajan ${ }^{6}$, Dr.T.Sarojini ${ }^{7}$ \\ ${ }^{1}$ Department of Maruthuvam, Srisairam Siddha Medical College and Research Centre, Chennai, India. \\ 2Department of Pharmaceutical Chemistry, Ultra College of Pharmacy, Madurai, India. \\ ${ }^{3}$ Department of Pharmaceutical Chemistry, Sankaralingam Bhuvaneswari College of Pharmacy, Sivakasi, India. \\ ${ }^{4}$ Department of Pharmaceutical Chemistry, Ultra College of Pharmacy, Madurai, India. \\ ${ }^{5}$ Department of Pharmaceutics, Sankaralingam Bhuvaneswari College of Pharmacy, Sivakasi, India. \\ ${ }^{6}$ Department of Pharmaceutical Chemistry, J.S.S.College of Pharmacy, Mysore, India. \\ ${ }^{7}$ Department of Udalthathuvam, Srisairam Siddha Medical College and Research Centre, Chennai, India. \\ *Corresponding author's E-mail: jebaseelanmpharm2000@rediffmail.com
}

Received: 18-05-2021; Revised: 15-07-2021; Accepted: 24-07-2021; Published on: 15-08-2021.

\begin{abstract}
The present study was carried out to determine the possible LC-MS and anti-microbial activity of plant extracts prepared from Muntingia calabura and phytochemical screening was demonstrated. The extracts from the plant parts like leaf were prepared in different solvents like petroleum ether, chloroform and ethanol. The highest antimicrobial potentials were observed for the ethanolic extracts against (Bacillus subtilis, Staphylococcus aureus, Klebsiella pneumoniae, Pseudomonas aeruginosa, Candida albicans) Its efficacy was comparable to the standard drug, amikacin. Significant amount of tannins, alkaloids, steroids and flavonoids were found. The present study provides evidence that solvent extract of $M$. calabura contains medicinally important bioactive compounds and this justifies the use of plant species as traditional medicine for treatment of various diseases. Likewise, the leaf extract of Muntingia calabura showed more zone of inhibition with fungus Candida albicans. This shows its antiseptic nature which might have been induced because of the components present.
\end{abstract}

Keywords: Medicinal plants, antimicrobial activity, phytochemical analysis.

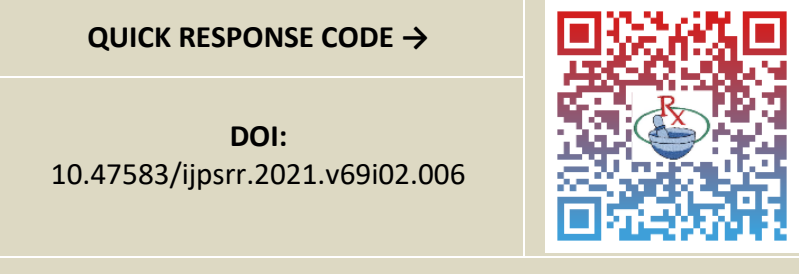

DOI link: http://dx.doi.org/10.47583/ijpsrr.2021.v69i02.006

\section{INTRODUCTION}

T here has been an increased urgency to discover novel antibiotics/anti microbial compounds due to emergence of drug resistant microorganisms. Therefore, an infection caused by antibiotic resistant microbes complicates conventional treatment causing prolonged illness and increases the death risks ${ }^{1}$

In the medical field, around $80 \%$ of the drugs tested are derived from natural sources or are modified semi synthetically ${ }^{2}$. The ultimate goal for any discovery is to offer appropriate and efficient antimicrobial drugs for the betterment of the patient. The acquired knowledge of plant extracts and phytochemicals usage possessing antimicrobial properties can be of great significance in therapeutic treatments. Many plant extracts show their antimicrobial traits, which is due to the presence of compounds synthesized in the secondary metabolism of the plant. These secondary metabolites mainly consists of phenolics including polyphenols, flavonoids, tannins and quinones known for their potent antioxidant, cytotoxic and antimicrobial activities ${ }^{3-6}$; alkaloids are mainly known for their cytotoxicity ${ }^{7-9}$

In the present work, we have selected Muntingia calabura L. (M. calabura), a shrub introduced to Southeast Asia from Tropical America. It is also known locally as Jamaica cherry, belonging to Elaeocarpaceae family ${ }^{10}$ It is often seen growing as roadside trees ${ }^{11}$, also used as an air pollution tolerance indicator. It is an annual plant, flowers throughout the year, its leaves are distinctively lanceolate in shape, with margins irregularly serrate and fruits are berries which turn red on maturation and are sweet in taste $^{12}$. In traditional knowledge, its leaves and roots are known to possess various medicinal applications. For example, in Peru, the extract from leaves and bark are used as antiseptics and in South America it is used to reduce gastric ulcers. Few places in Philippines, the flowers are used to treat headache and for relief of incipient colds. The main basis for carrying out the present study is attributed to the presence of several bioactive compounds possessing anti-inflammatory, anti-nociceptive, antioxidant activity ${ }^{13}$ with few reports on antimicrobial activity of the leaves ${ }^{14}$. Keeping all the biomedical application potential of $M$. calabura, we have presented the antimicrobial and antifouling activity of the crude extracts prepared in different solvents from the leaves, flower, roots, fruits and stems of $M$. calabura against the selected Gram positive and Gram negative bacteria: Escherichia coli, Salmonella 
typhimurium, Pseudomonas aeruginosa, Staphylococcus aureus, Bacillus subtilis, Bacillus megaterium, Klebseilla pnemoniae. The phytochemical analysis was also carried out being responsible for the bioactive properties of the extracts.

\section{MATERIALS AND METHODS}

\section{Collection of samples}

The leaf Muntingia calabura was collected in Madurai district of Tamilnadu during the first week end of December. This plant was authenticated by the Department of the Botany, American College, Madurai.

\section{Extracted plant material powder by maceration method.}

The shade dried material (250gms) was extracted with petroleum ether $\left(60^{\circ} \mathrm{C}-80^{\circ} \mathrm{C}\right)$ in soxhlet apparatus. After the completion of the extraction, the solvent was removed. The marc left petroleum ether extraction was dried and extracted with chloroform in soxhlet apparatus. The solvent was removed after the completion of extraction. The marc left after the chloroform extraction was dried and then extracted with ethanol in soxhlet apparatus. The solvent was removed after the extraction was completed, the solvent was taken out and concentrated.

\section{Preparation of sample for phytochemical screening}

The plant parts (leaf) were cleaned, dried and powdered with the help of mixer grinder separately. Methanol extracts were prepared and concentrated using rotary evaporator and stored at 4 으 in air tight containers.

\section{Microbial samples}

Microorganisms tested in this study were: Escherichia coli, Salmonella typhimurium, Pseudomonas aeruginosa, Staphylococcus aureus, Bacillus subtilis, Bacillus

Methodology for phytochemical screening ${ }^{15-18}$

Chemical tests were carried out on the extract and on the powdered specimens using standard procedures based on the protocols of Edeoga et al,2005; Harborne,1973 and Sofowara,1993; to identify the various constituents present.

\section{Test for Alkaloids}

Test solution ( $1 \mathrm{ml}$ ) was taken in test tube and few drops of Mayer's reagent (Potassium mercuric iodine solution) were added into it and then cream color precipitate was observed. To a few $\mathrm{ml}$ of filtrate, 1 or $2 \mathrm{ml}$ of Dragendorff's reagent was added by the side of the test tube. A prominent red precipitate indicates test as positive.

\section{Test for Tannins}

To test solution added $10 \mathrm{ml}$ distilled water, then filtered, in the filtrate $2 \mathrm{ml} \mathrm{FeCl}_{3}(10 \%)$ was added blue-black or green precipitate formed, indicate the presence of tannins.

\section{Test for Cardiac Glycosides}

$5 \mathrm{ml}$ of each extracts was treated with $2 \mathrm{ml}$ of glacial acetic acid containing one drop of ferric chloride solution. This was underlayed with $1 \mathrm{ml}$ of concentrated sulphuric acid. A brown ring of the interface indicates a deoxysugar characteristic of cardenolides. A violet ring may appear below the brown ring, while in the acetic acid layer, a greenish ring may form just gradually throughout thin layer.

\section{Test for Flavonoid}

$5 \mathrm{ml}$ of dilute ammonia solution were added to a portion of the aqueous filtrate of each plant extract followed by addition of concentrated $\mathrm{H}_{2} \mathrm{SO}_{4}$. A yellow colouration observed in each extract indicated the presence of flavonoids. The yellow colouration disappeared on standing.

\section{Test for Terpenoids}

To the test solution, added $2 \mathrm{ml}$ of chloroform and $1 \mathrm{ml}$ $\mathrm{H}_{2} \mathrm{SO}_{4}$, reddish brown color at interface, indicate the presence of terpenoids.

\section{Test for Saponins}

$2 \mathrm{gm}$ of the powdered sample was boiled in $20 \mathrm{ml}$ of distilled water in a water bath and filtered. $10 \mathrm{ml}$ of the filtrate was mixed with $5 \mathrm{ml}$ of distilled water and shaken vigorously for a stable persistent froth. The frothing was mixed with 3 drops of olive oil and shaken thoroughly, then observed for the formation of emulsion thereafter in plant sample (filterate/powder).

\section{Test for Steroids}

$2 \mathrm{ml}$ of acetic anhydride was added to $0.5 \mathrm{gm}$ ethanolic extract of each sample with $2 \mathrm{ml} \mathrm{H} 2 \mathrm{SO}$. The colour changed from violet to blue or green in some samples indicating the presence of steroids.

\section{ANTI MICROBIAL STUDY}

The petroleum ether extracts and Ethanol extracts are subjected to antimicrobial screening using disc diffusion method.

\section{Disc Diffusion Method: ${ }^{19-23}$}

\section{Muller-Hinton Agar Medium:}

\section{Preparation of Muller-Hinton Agar:}

Muller Hinton Agar medium is prepared from a commercially available dehydrated base according to the manufacture's instruction. Immediately after autoclaving it is allowed to cool in a $45-50^{\circ} \mathrm{c}$ water bath. The freshly prepared and cooled medium is poured into a glass Petridishes on level horizontal surface to give a uniform depth of approximately $4 \mathrm{~mm}$. The agar medium is allowed to cool. 


\section{Preparation of Dried Filter Paper Discs:}

Whatmann filter paper no: 1 is prepared discs approximately $8 \mathrm{~mm}$ in diameter which is placed in a petridish and sterilized in a hot air oven. This sterilized disc is then loaded with the extracts dissolved in dimethyl formamide with the required concentration using a micropipette and it is dried. Amikacin is used as standard disc. The strength of $500 \mathrm{mg}$ of aqueous \& petroleum ether extract of Muntingia calabura are used for our antimicrobial studies.

\section{Storage of Antimicrobial Disc:}

The prepared disc are stored in a closed air tight container in refrigerator until use.

\section{Inoculation of Test Plates:}

A sterile cotton swab was dipped into the cultures (Bacillus subtilis, Staphylococcus aureus Klebsiella pneumoniae, Pseudomonas aeruginosa, Candida albicans) the swab was rotated several times and pressed firmly on the inside wall of the tube to remove excess inoculums from the swab over the sterile entire agar surface. The procedure is repeated by streaking two more time, rotating the plate 60 ㅇ each time to ensure an even distribution of inoculums. The lid was left after for 3-5 minutes, but not more than 15 minutes to allow for any excess moisture to be absorbed before applying the drug impregnated discs.

\section{Application of Discs to Inoculated Agar Plates:}

Each disc is pressed down to ensure complete contact with the agar surface. The disc is distributed evenly so that they are not closer to each other. The plates are inverted and placed in an incubator set to $35^{\circ} \mathrm{c}$ within 15 minutes after the disc are applied.

\section{Reading Plates and Interpreting Results:}

After 24 hrs of incubation, each plate is examined. The diameter of the zones of complete inhibition are measured.

\section{RESULT AND DISCUSSION}

\section{Phytochemical Screening}

\section{Qualitative estimation}

In the present study, preliminary phytochemical screening of the extract of leaves of experimental plant Muntingia calabura, revealed the presence of various bioactive components such as alkaloids, saponins, tannins, cardiac glycosides, steroids, flavonoids, terpenoids etc were identified. (Table $1 \& 2$ )

Table 1: Phytochemical screening of leaf parts of Muntingia calabura

\begin{tabular}{|c|c|c|c|c|c|c|c|}
\hline S.NO & Tannins & Saponins & Steroids & Terpenoids & Flavonoids & Alkaloids & Cardiac glycosides \\
\hline+ or - & + & + & + & + & + & + & + \\
\hline
\end{tabular}

Table 2: Yield of extracts

\begin{tabular}{|c|l|c|c|}
\hline S.NO & \multicolumn{1}{|c|}{ Solvent } & Colour of the Extract & Percentage of yield \\
\hline 1 & Petroleum ether & Dark brown & $3 \%$ \\
\hline 2 & Chloroform & Greenish black & $2.5 \%$ \\
\hline 3 & Ethanol & Dark brown & $2.5 \%$ \\
\hline
\end{tabular}

Antimicrobial activity on bark and leaf of the Ethanol and Petroleum ether extract of Muntingia Calabura STUDIES ON GRAM POSITIVE BACTERIA

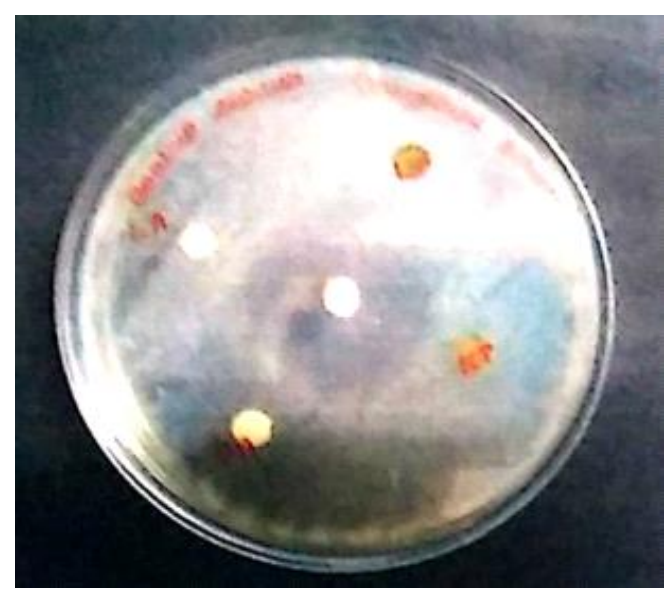

Figure 4A: Bacillus substilis

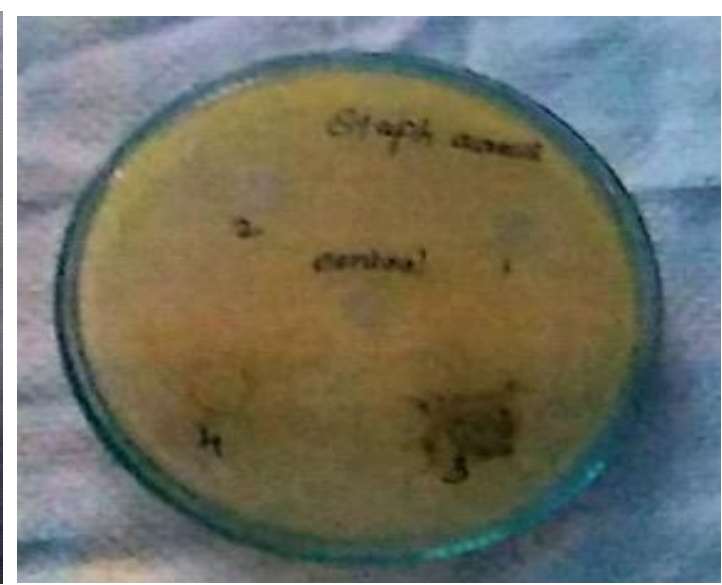

Figure 4B: Staphylococcus aureus 


\section{STUDIES ON GRAM NEGATIVE BACTERIA}

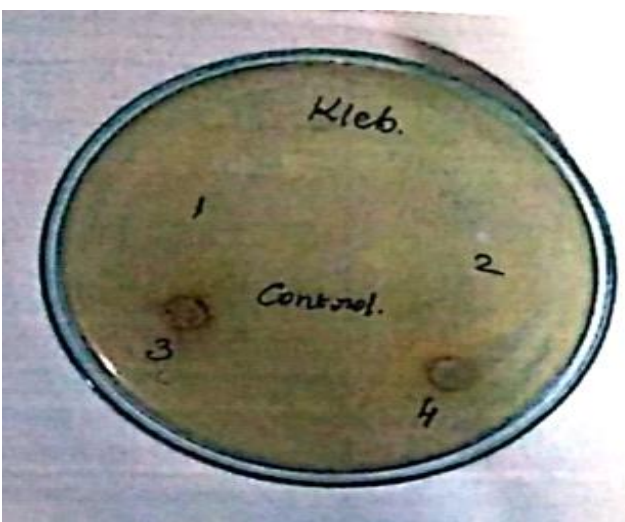

Figure 4C: Klebsiella pneumoniae

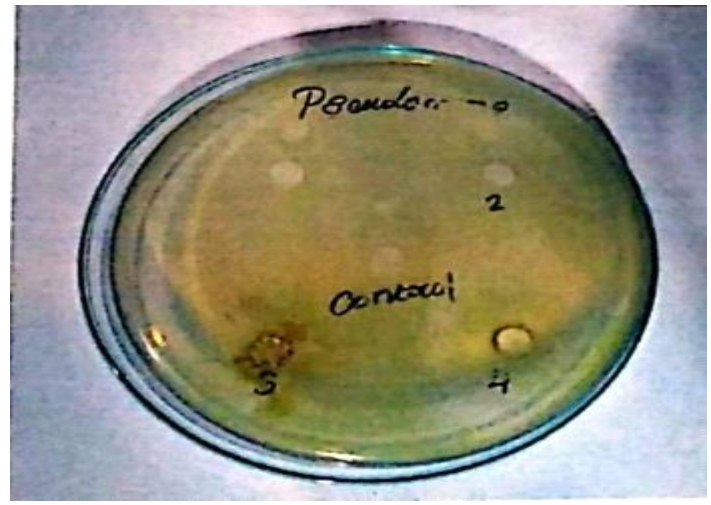

Figure 4D: Pseudomonas aeruginosa

\section{STUDIES ON FUNGUS}

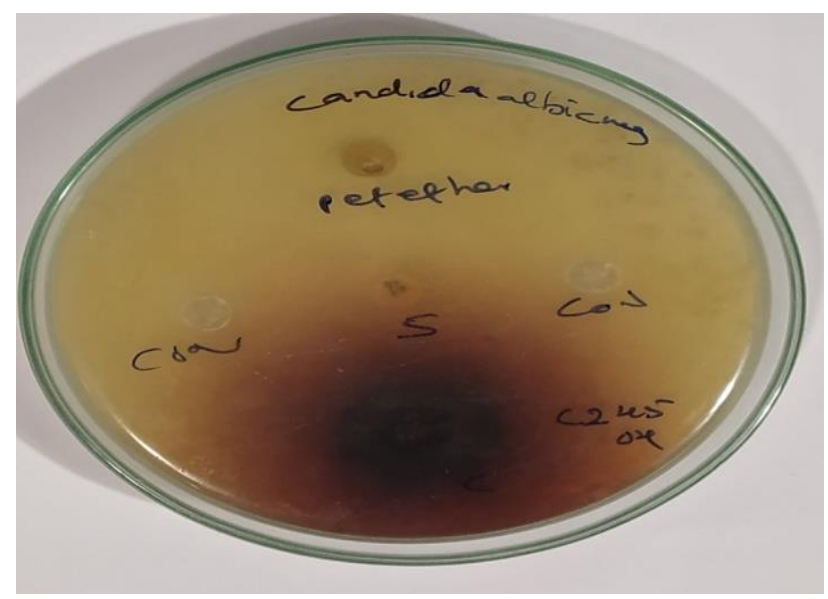

Figure 4E: Candida albicans

Table 3: Antimicrobial Activity of Ethanol and Petroleum Ether Extract of Muntingia calabura

\begin{tabular}{|c|c|c|c|c|c|c|}
\hline \multirow[t]{2}{*}{ S.NO } & \multirow[t]{2}{*}{ Name of the Organism } & \multicolumn{5}{|c|}{ Zone Of Inhibition $(\mathrm{cm})$} \\
\hline & & $\begin{array}{c}\text { A } \\
500 \mathrm{mg} / \mathrm{ml}\end{array}$ & $\begin{array}{c}\text { B } \\
500 \mathrm{mg} / \mathrm{ml}\end{array}$ & $\begin{array}{c}\mathrm{C} \\
500 \mathrm{mg} / \mathrm{ml}\end{array}$ & $\begin{array}{c}\text { D } \\
500 \mathrm{mg} / \mathrm{ml}\end{array}$ & $\begin{array}{c}\text { S } \\
\text { STD }\end{array}$ \\
\hline $\begin{array}{c}1 . \\
2 .\end{array}$ & $\begin{array}{l}\text { Gram Positive Bacteria } \\
\text { Bacillus substilus } \\
\text { Staphylococcus aureus }\end{array}$ & $\begin{array}{c}\mathrm{R} \\
1.5\end{array}$ & $\begin{array}{l}0.9 \\
1.3\end{array}$ & $\begin{array}{l}0.9 \\
1.2\end{array}$ & $\begin{array}{l}1.1 \\
1.8\end{array}$ & $\begin{array}{l}3.4 \\
2.2\end{array}$ \\
\hline $\begin{array}{l}1 . \\
2 .\end{array}$ & $\begin{array}{l}\text { Gram Negative Bacteria } \\
\text { Klebsiella pneumonia } \\
\text { Pseudomonas aeruginosa }\end{array}$ & $\begin{array}{l}1.2 \\
0.9\end{array}$ & $\begin{array}{l}1.1 \\
1.3\end{array}$ & $\begin{array}{l}1.4 \\
1.1\end{array}$ & $\begin{array}{l}1.5 \\
1.0\end{array}$ & $\begin{array}{l}1.8 \\
1.2\end{array}$ \\
\hline 1. & $\begin{array}{l}\text { Fungus } \\
\text { Candida albicans }\end{array}$ & $\mathrm{R}$ & 1.0 & $\mathrm{R}$ & 0.8 & 3.5 \\
\hline $\begin{array}{l}1=A \\
2=B \\
3=C \\
4=D \\
S=B \\
S=F L \\
R=R\end{array}$ & $\begin{array}{l}\text { Ethanol extract of leaf } \\
\text { Ethanol extract of bark } \\
\text { Petroleum ether extract of } \\
\text { Petroleum ether extract of } \\
\text { terial Standard - Amikacin } \\
\text { igal Standard- Ketoconazole } \\
\text { sistant }\end{array}$ & & & & & \\
\hline
\end{tabular}

\section{Anti-Microbial Study}

The leaf extract of Muntingia calabura was tested for anti microbial study using petroleum ether, chloroform, ethanol extracts. Among these three extracts ethanol extract is more active than other solvents like chloroform and petroleum ether. 


\section{REFERENCES}

1. Barza $M$, Travers $K$, Excess infections due to antimicrobial resistance: the "Attributable Fraction". Clin Infect Dis 2002;34 (3):S126-30.

2. Newman D J, Cragg GM, Natural products as sources of new drugs over the 30 years from 1981 to 2010. J Nat Prod 2012; 75(3): 311-35.

3. Pahari B, Chakraborty S, Chaudhuri S, Sengupta B, Sengupta $\mathrm{PK}$, Binding and antioxidant properties of therapeutically important plant flavonoids in biomembranes: insights from spectroscopic and quantum chemical studies. Chem Phys Lipids. 2012; 165 (4): 488-96.

4. Dai J, Mumper RJ, Plant phenolics: extraction, analysis and their antioxidant and anticancer properties. Molecules. 2010; 15 (10):7313-52.

5. Wong IL, Chan K F, Chen YF, Lun ZR, Chan TH, Chow LM. In vitro and in vivo efficacy of novel flavonoid dimers against cutaneous leishmaniasis. Antimicrob Agents Chemother 2014;58 (6):3379-88.

6. Cushnie TP, Lamb AJ, Recent advances in understanding the antibacterial properties of flavonoids. Int J Antimicrob Agents 2011; 38 (2): 99- 107.

7. Kulkarni SK, Dhir A, Berberine: a plant alkaloid with therapeutic potential for central nervous system disorders. Phytother Res, 2010; 24 (3): 317-24.

8. Panis C, Lemos LG, Victorino VJ, Herrera AC, Campos FC, Colado Simao, AN, Pinge-Filho P, Cecchini A L, Cecchini, R. Immunological effects of taxol and adryamicin in breast cancer patients. Cancer Immunol Immunother .2012; 61 (4): 481-8.

9. Zhang $X$, Oh M, Kim S, Kim J, Kim H, Houghton PJ, Whang W. Epimediphine, a novel alkaloid from Epimedium koreanum inhibits acetylcholinesterase. Nat Prod Res, 2013;27 (12):1067-74.

10. Morton JF, Jamaica Cherry. Fruits of Warm Climates, Miami 1987, 65-69.

11. Ragragio EM, D P A, Datuin K, Sia Su GL, Sia Su MLL., Air pollution tolerance index of trees in selected areas in the Philippines. J Appl Phytotechnol Environ Sanit 2014; 3(1):1722.
12. Bayer C, CM., Fay MF., Muntingiaceae, a new family of dicotyledons with malvalean affinities. Taxon 1998; 47 (1):3742.

13. Zakaria, Z A.; Nor Hazalin NA. M, Zaid, SNH M.; Ghani MA.; Hassan MH.; Gopalan, H.K.; Sulaiman, MR., Antinociceptive, anti-inflammatory and antipyretic effects of Muntingia calabura aqueous extract in animal models. Journal of Natural Medicines 2007;61(4):443-448.

14. Sufian, AS.; Ramasamy K., Ahmat N.; Zakaria, Z. A.; Yusof, M. I., Isolation and identification of antibacterial and cytotoxic compounds from the leaves of Muntingia calabura L. J Ethnopharmacol. 2013; 146(1): 198-204.

15. Edeoga H.O, Okwu D.E. Mbaebie BO. Phytochemical constituents of some Nigerian medicinal Plants. African Journal of Biotechnology, 2005; 4(7): 685-688.

16. Harada H, Yamashita U, Kurihara H, Fukushi E, Kawabata J. Kamei Y. Antitumor activity of palmitic acid found as a selective cytotoxic substance in a marine red alga. AnticancerRes, 2002; 22(5): 2587-2590.

17. Sofowara, A. Medicinal plants and traditional medicine in Africa. Spectrum Books Ltd.,Ibadan, Nigeria, 1993; 289.

18. Harborne J.B. Phytochemical methods, London. Chapman and Hall Ltd. 1973; 49: 188.

19. Dr.s.vijayan, Annsteffy Thomas. Antimicrobial activity by screening method from Muntingia calabura extract. International journal of recent scientific research. 2018;91(B): 22991-22996.

20. ND.Mahmood, NLM.Nasir, S.Rofiee. Phytochemical analysis and pharmacological Activity of Muntingia calabura extract. Pharm Biol, 2014; 52(12): 1598-1623.

21. ZA Zakaria, CA Fatimah, AMAat jais. In vitro antimicrobial activity of Muntingia calabura extract. African Journal of Microbiology Research .2010;4 (4):304-308.

22. Singh R, lyes Prasad S, Deshmukhn, Cupta U. Phytochemical analysis of Muntingia calabura extract possessing anti microbial and anti fouling activities. International Journal of Pharmacognosy and Phytochemical Research 2017; 9(6); 826-832.

23. González-Lamothe R, Mitchell G, Gattuso M. Plant antimicrobial agents and their effects on plant and human pathogens. International journal of molecular sciences. 2009; 10(8): 3400-3419.

Source of Support: The author(s) received no financial support for the research, authorship, and/or publication of this article. Conflict of Interest: The author(s) declared no potential conflicts of interest with respect to the research, authorship, and/or publication of this article.

For any question relates to this article, please reach us at: editor@globalresearchonline.net New manuscripts for publication can be submitted at: submit@globalresearchonline.net and submit_ijpsrr@rediffmail.com 